\title{
ダイポール波源近傍の多層媒質による電磁シールド効果
}

\begin{tabular}{|c|c|c|c|}
\hline 生目 & 吉村 & 慶之 & （金沢大学, 石川目工業試酸場 \\
\hline 正 員 & 長野 & 勇 & (金沢大学) \\
\hline 非会員 & 八木谷 & 聡 & (金沢大学) \\
\hline 非会員 & 大浦 & 利夫 & (石川県工業試験場) \\
\hline
\end{tabular}

\section{Electromagnetic Shielding Effectiveness of a Multilayered Medium in the Vicinity of a Dipole Source}

\author{
Yoshiyuki Yoshimura, Student member (Kanazawa Univ., Indust. Res. Inst. of Ishikawa), \\ Isamu Nagano, Member (Kanazawa Univ.), Satoshi Yagitani, Non-member (Kanazawa Univ.), \\ and Toshio Ooura, Non-member (Indust. Res. Inst. of Ishikawa)
}

Electromagnetic shielding is popularly used to suppress electromagnetic noise generated from electronic equipments. It is important to know the shielding mechanism in designing the effective shielding. In this paper, the electromagnetic field in the vicinity of a horizontal multilayered medium with either a magnetic or an electric dipole source was calculated theoretically by a Sommerfeld integral, in which a spherical wave radiated from the dipole source is expanded into a large number of cylindrical waves. The integration formulas are derived and they are numerically calculated for investigation of shielding effectiveness and Poynting flux. We calculate electromagnetic shielding effectiveness to confirm the applicability of this analysis. Calculation results are in good agreement with measurement results. To clarify the shielding mechanism, Poynting flux from either a magnetic or an electric dipole source in the vicinity of shielding materials and inside the shielding materials is demonstrated. The electromagnetic wave with the shield is attracted by the shielding material, and shielding effectiveness depends on energy flow along the shielding material.

キーワード : 多層媒質, ダイポール, Sommerfeld 積分, 電磁シールド, 電力流

\section{1.まえがき}

電子情報通信技術の発達により，不要電磁波が原因とな る電子機器の捠動作が問題となっており，機器は不要電磁 波を放射し難く受计難い，すなわち，電磁両立性 (EMC) をもたせた製品開発が求められている。そこで，筐体に高 導電材を選定することにより電磁波シールドを講じること が一つの対策手段として行われている．したがって，有効 な EMC対策を行うにはそのシールド特性をよく把握して おくことが重要である。ここでは，材料の誘電率，透磁率， 導電率等の電気定数を用いて理論解析的にシールドのメ力 ニズムを把握することとした。

シールド効果を理論的に考察する場合，一般にシェルク ノフの式がよく用いられる(1)。これは，伝送線路理諭を用 いた無限平板に対する平面波のシールド効果を簡単な式に より颜密に与えている．ただし，波源が存在するような近 傍電磁界を取り扱う場合には綮密とはならない，そこで， この式に補正を加えることにより，ダイポール波源を考虑 した場合のシールド効果が求められている(2).また，ダイ
ポール波源と観測点が任意の位置にある場合のシールド効 果が伝送線路理論を用いて，電磁界の積分表示により縓密 に求められている(3)．以上は単層平板に対寸る解析である が，より効果的なシールド性能の向上を追求した場合，材 料内部で多重反射損を多くとることができるシールド材の 多層化が考えられる：このような多層媒質の解析として， 平面波が媒質にTM入射した場合の縓密解が与えられてい る( ル波源を有するシールド効果が平面波の積分表示によって 求められている(5).

シールドのメカニズムをより明確にするためには，シー ルド材によって電磁界がどのように変化したか，すなわち 電力流の入出力を求めることが重要であると考えられる. しかしながら，これまでに波源近傍に設置された多層シー ルド材の周辺，または内部空閒電磁界を解析し，シールド 効果と関連付けた報告はされていない，この電磁界を解析 するためには，近年F DTD法がよく利用されているが， 吅オーダの薄板シールドを取り扱う場合は，シールド材 内部のメッシュサイズと空間メッシュサイズとの差が大き 
すぎるため適用が困難であるそこで，本論文では多層シ 一ルド材に対してダイポール波源を垂直，または水平に設 㯰した場合の電磁界を円筒波の積分表示式を用いて理論的 に求めた。をとして，実験結果と比較することにより本解析 手法の妥当性を検証した. 次に，材料間に空隙を設定した 場合のシールド効果を求め，空隙の大きさとシールド効果 との関係を示した．また，多層媒質近傍，あるいは内部に おける電力流の時間平均值をべクトル表示し，シールドの メカニズムを検討した。

\section{2. 解析モデルと座標系}

無限平板を仮定した多層媒質モデルの座標系を図 1 に示 す. 座標原点より $=h_{0}$ の位置に磁気，あるいは電気ダイポ 一ル波源を設定する．ダイポール軸は媒質に対して，垂直 ( $\mathrm{z}$ 方向)，または水平 (x力向)を想定し，媒質は各層ごとに 均質であると仮定する。

\section{3.ダイポール波源近傍における電磁界解析}

〈3・1〉垂直磁気ダイポール

（1）境界条件 磁気ダイポール波源のへルツベクトル $\Pi_{\mathrm{m}}$ を用いて，電磁界は式(1)，(2)より求めることができ $\zeta^{(6)}$.

$$
\begin{aligned}
& \mathbf{E}=-\mathrm{j} \omega \mu \nabla \times \Pi_{\mathrm{m}} \\
& \mathbf{H}=\nabla \nabla \cdot \Pi_{\mathrm{m}}+k^{2} \Pi_{\mathrm{m}}
\end{aligned}
$$

ここで，Eは電界，Hは磁界， $\omega$ は角周波数， $\mu$

は透磁率, $k$ は波数である.

$\mathrm{xy}$ 平面上に設固された媒質 $i$ 層と媒質 $i+1$ 層との間にお打 万境界条件式は，式(1)，（2）電磁界の接線成分の連続性 に適用することにより式 (3)，(4)となる.

$$
\mu_{i} \Pi_{\mathrm{m} z t}=\mu_{i+1} \Pi_{\mathrm{m} z i+1}
$$

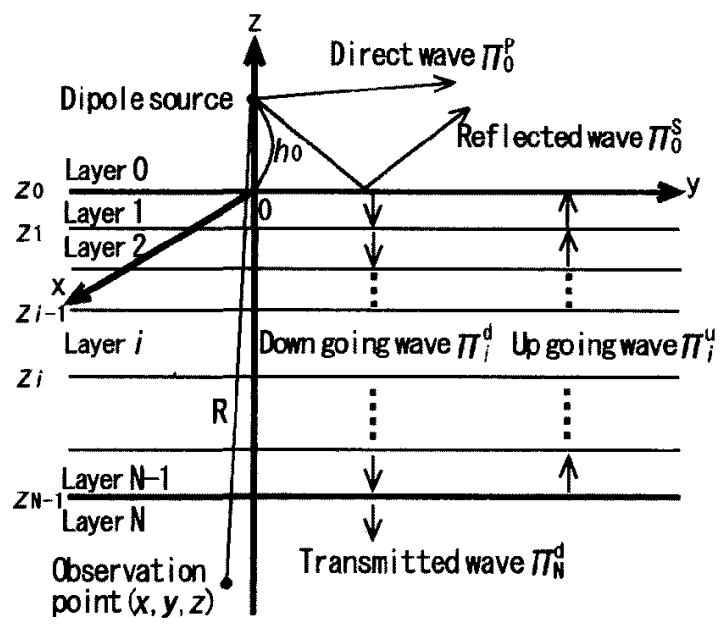

図 1 多層媒質モデルの座標系

Fig.1 Coordinates for multilayered media model. $\frac{\partial \Pi_{\mathrm{m} z l}}{\partial z}=\frac{\partial \Pi_{\mathrm{m} z i+1}}{\partial z}$

ここで， $\Pi_{\text {mux }}$ は層におけるへルツベクトルのz成

分である。

（2）各畨における境界条件の逼用垂直磁気ダイポー ル波源の $\prod_{\mathrm{m}}$ は時間依存性を消去すると以下の式(5)で表さ れる。

$\Pi_{\mathrm{m}}=\frac{n S I}{4 \pi} \frac{\mathrm{e}^{-\mathrm{j} k R}}{R} \mathbf{i}_{x}$

ここで，nはループ巻き数， $S$ はループ面積，Iは

電流， $R$ は波源からの距晟である.

球面波を円筒波の合成により表現する Sommerfeld 積分 表示を用いると，式(5) は：層において上昇波を表す式(6)， 下降波を表す式(7)となる(6) 。たた これらを加え合わせ た式(8)が i層のヘルツベクトルとなる.

$$
\begin{aligned}
\Pi_{\mathrm{m} z i}^{\mathrm{u}} & =\frac{n S I}{4 \pi} \int_{0}^{\infty} F_{\mathrm{m} j}^{\mathrm{u}}(\lambda) J_{0}(\lambda r) e^{-v_{i}\left(z-z_{i-1}\right)} \lambda d \lambda \\
\Pi_{\mathrm{m} z}^{\mathrm{d}} & =\frac{n S I}{4 \pi} \int_{0}^{\infty} F_{\mathrm{m} z i}^{\mathrm{d}}(\lambda) J_{0}(\lambda r) e^{\gamma_{i}\left(z-z_{i-1}\right)} \lambda d \lambda \\
& こ こ て ゙, \quad v_{i}=\sqrt{\lambda^{2}-k_{i}^{2}} \text { である. } \\
\Pi_{\mathrm{m} z i} & =\Pi_{\mathrm{m} z i}^{\mathrm{u}}+\Pi_{\mathrm{m} z j}^{\mathrm{d}}
\end{aligned}
$$

ここで， $\Pi_{\mathrm{m} u}$ の上付き添字岒上昇波，dは下降波， $F_{\mathrm{a}}$ は未知数で入の関数であり，添字は $\Pi_{\mathrm{m}}$ 之同様 である。また，J第0次第1種ベッセル関数，rは 円筒座標の半径方向距離, $\lambda$ は積分定数, $z_{\mu}$ は $\mathrm{i}$ 層 までのz方向の距離である.

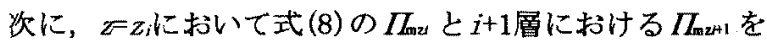
境界条件式 (3)，(4)に代入すると，未知数 $F_{\mathrm{mu}}(\lambda)$ は式(9) に示す行列によって表現できる.ここで，未知数 $F_{\mathrm{mxx}}(\lambda)$ の变数入は省略する.

$$
\begin{aligned}
& {\left[\begin{array}{c}
F_{\mathrm{mx}}^{\mathrm{u}} \\
F_{\mathrm{m} x}^{\mathrm{d}}
\end{array}\right]=\frac{1}{2 \mu_{i} v_{i}}\left[\begin{array}{c}
\left(\mu_{i+1} v_{i}+\mu_{i} v_{i+1}\right) e^{v_{i} h_{i}} \\
\left(\mu_{i+1} v_{i}-\mu_{i} v_{i+1}\right) e^{-v_{i} h_{i}}
\end{array}\right.} \\
& \left.\begin{array}{c}
\left(\mu_{i+1} v_{i}-\mu_{i} v_{i+1}\right) e^{v_{i} h_{i}} \\
\left(\mu_{i+1} v_{i}+\mu_{i} v_{i+1}\right) e^{-v_{i} h_{i}}
\end{array}\right]\left[\begin{array}{l}
F_{\operatorname{mat+1}}^{\mathrm{u}} \\
F_{\mathrm{mat}+1}^{\mathrm{d}}
\end{array}\right] \\
& \text { ここで, } h_{i}=z_{i}-z_{i-1} \text { である. } \\
& =\left[\begin{array}{ll}
c_{i 11} & c_{f 12} \\
c_{i 21} & c_{i 22}
\end{array}\right]\left[\begin{array}{l}
F_{\mathrm{mazi+1}}^{\mathrm{u}} \\
F_{\mathrm{mz} i+1}^{\mathrm{d}}
\end{array}\right]
\end{aligned}
$$

式(10)の未知数行列は， $c_{n 11}, c_{\mathrm{i} 12}, c_{\mathrm{i} 21}, c_{i 22}$ 含む $2 \times 2$ 含 既知数行列を係数とした濑化式であり，これらを 0 層から 層まで展開すると最終的に式(11) となり，0層の未知数は 係数行列の積とN層の未知数によって表される（付録）。

$$
\begin{aligned}
{\left[\begin{array}{c}
F_{\mathrm{mz} 0}^{\mathrm{S}} \\
e^{-v_{0} h_{0}}
\end{array}\right] } & =\prod_{i=0}^{\mathrm{N}-1}\left[\begin{array}{ll}
c_{i 11} & c_{i 12} \\
c_{i 21} & c_{i 22}
\end{array}\right]\left[\begin{array}{c}
0 \\
F_{\mathrm{mzN}}^{\mathrm{d}}
\end{array}\right] \\
& =\left[\begin{array}{ll}
C_{11} & C_{12} \\
C_{21} & C_{22}
\end{array}\right]\left[\begin{array}{c}
0 \\
F_{\mathrm{mzN}}^{\mathrm{d}}
\end{array}\right]
\end{aligned}
$$

ここで, 左辺の末知数の上付き添字Sは0層におけ る反射波成分を表 $L, C_{11} ， C_{22} ， C_{21} ， C_{22}$ は既知数行 
列を乗算した結果である。

式(12)を展開することにより，末知数は式(13)によって 求めることができる。

$$
\left[\begin{array}{l}
F_{\operatorname{mz} 0}^{\mathrm{s}} \\
F_{\mathrm{maN}}^{\mathrm{d}}
\end{array}\right]=\left[\begin{array}{cc}
-1 & C_{12} \\
0 & C_{22}
\end{array}\right]^{-1}\left[\begin{array}{c}
0 \\
e^{-v_{0} h_{0}}
\end{array}\right]
$$

得られた未知数を Sommerfeld 積分表示式の合成である 付録式 $(A \cdot 3) ，(A \cdot 13)$ に代入することにより0層(波源)，ま たはN層 (観測点)における 知数を溸化式への代入を繰り返すことにより，その他の未 知数が逐次計算でき各層の $\Pi_{\mathrm{m}}$ が得られる、次に,この を式(1)，(2)に代入することにより各層の電磁界が求めら れる。

〈3.2〉水平碰気ダイポール

（1）境界条件 水平磁気ダイボール波源の $\Pi_{\mathrm{m}}$ はx成分 に加え，層の不均質性を反映させるため成分も必要亡な

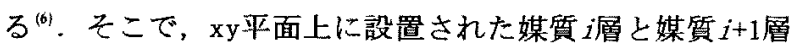
との閒における境界条件は，電磁界の接線成分の連続性上 り以下となる.

$$
\begin{aligned}
& \mu_{i} \Pi_{\mathrm{m} x i}=\mu_{i+1} \Pi_{\mathrm{m} z i+1} \\
& \mu_{i} \frac{\partial \Pi_{\mathrm{mx} i}}{\partial z}=\mu_{i+1} \frac{\partial \Pi_{\mathrm{m} v+1}}{\partial z} \\
& \frac{\partial \Pi_{\mathrm{m} i}}{\partial x}+\frac{\partial \Pi_{\mathrm{m} z i}}{\partial z}=\frac{\partial \Pi_{\mathrm{m} x i+1}}{\partial x}+\frac{\partial \Pi_{\mathrm{m} z+1}}{\partial z} \\
& k_{i}^{2} \Pi_{\mathrm{m} x i}=k_{i+1}^{2} \Pi_{\mathrm{m} x i+1}
\end{aligned}
$$

（2）各層における境界条件の適用ｉ層におけるダイ ポール朝方向 (x軸方向)の川学を Sommerfeld 積分表示式を 用いると式(18)，(19）となり，z成分の積分表示式は境界 条件式(16)上り類推して式(20)，(21) と仮定する ${ }^{(8)}$.

$$
\begin{aligned}
& \Pi_{\mathrm{mad}}^{\mathrm{u}}=\frac{n S I}{4 \pi} \int_{0}^{\infty} F_{\operatorname{mid}}^{\mathrm{u}}(\lambda) J_{0}(\lambda r) e^{-r_{i}\left(z-z_{i-1}\right)} \lambda d \lambda \\
& \Pi_{\mathrm{mxi}}^{\mathrm{d}}=\frac{n S I}{4 \pi} \int_{0}^{\infty} F_{\mathrm{mov}}^{\mathrm{d}}(\lambda) V_{0}(\lambda r) e^{\nu_{\mathrm{f}}\left(z-z_{t-1}\right)} \lambda d \lambda \\
& \Pi_{\mathrm{m} z}^{\mathrm{u}}=\frac{n S I}{4 \pi} \int_{0}^{\infty} \frac{\partial}{\partial x} F_{\mathrm{m} z i}^{\mathrm{u}}(\lambda) J_{0}(\lambda r) e^{-r_{i}\left(z-z_{j-1}\right)} \lambda d \lambda \\
& \Pi_{\mathrm{m} z i}^{\mathrm{d}}=\frac{n S I}{4 \pi} \int_{0}^{\infty} \frac{\partial}{\partial x} F_{\mathrm{m} z i}^{\mathrm{d}}(\lambda) J_{0}(\lambda r) e^{\nu,\left(z-z_{i-1}\right)} \lambda d \lambda
\end{aligned}
$$

垂直ダイポールの場合と同様にi層と $i+1$ 層の $\Pi_{\mathrm{m}}$ を $Z=Z_{i}$ において境界条件式(14)～(17)に代入すると，末知数 $F_{\mathrm{m} \times \text {, }}$ $F_{\mathrm{m} z}$ は $4 \times 4$ の保数行列と $F_{\mathrm{mx}+1}, F_{\mathrm{mz}+1}$ の行列による濑化式 (22)，(23)によって表現できる。これを0層からN層まで繰 り返し展開することにより最終的に式 (24)となり，書き改 めると式(25)となる.

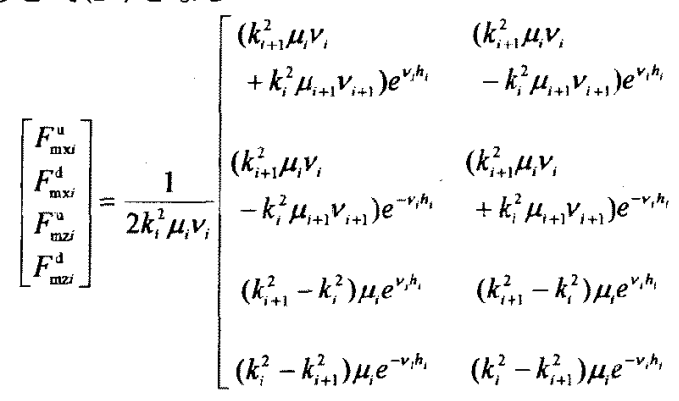

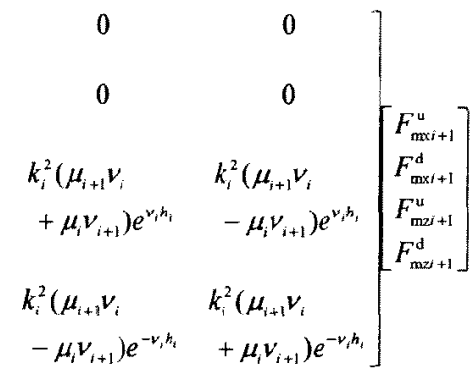

$$
\begin{aligned}
& =\left[\begin{array}{llll}
c_{i 13} & c_{i 12} & c_{i 13} & c_{i 14} \\
c_{i 21} & c_{i 22} & c_{i 23} & c_{i 24} \\
c_{i 31} & c_{i 32} & c_{i 33} & c_{i 34} \\
c_{i 41} & c_{i 42} & c_{i 43} & c_{i 44}
\end{array}\right]\left[\begin{array}{l}
F_{\mathrm{mx} i+1}^{\mathrm{u}} \\
F_{\mathrm{m} x i+1}^{\mathrm{d}} \\
F_{\mathrm{mz} i+3}^{\mathrm{u}} \\
F_{\mathrm{mz} i+1}^{\mathrm{d}}
\end{array}\right] \\
& {\left[\begin{array}{c}
F_{\mathrm{mx0}}^{\mathrm{S}} \\
e^{-v_{0} h_{0}} \\
F_{\mathrm{m} 20}^{\mathrm{s}} \\
0
\end{array}\right]=\prod_{i=0}^{N-1}\left[\begin{array}{cccc}
c_{i 11} & c_{i 12} & c_{i 13} & c_{i 14} \\
c_{i 21} & c_{i 22} & c_{i 23} & c_{i 24} \\
c_{i 31} & c_{i 32} & c_{i 33} & c_{i 34} \\
c_{i 41} & c_{i 42} & c_{i 43} & c_{i 44}
\end{array}\right]\left[\begin{array}{c}
0 \\
F_{\mathrm{mmN}}^{\mathrm{d}} \\
0 \\
F_{\mathrm{mzN}}^{\mathrm{d}}
\end{array}\right]} \\
& =\left[\begin{array}{llll}
C_{11} & C_{12} & C_{13} & C_{14} \\
C_{21} & C_{22} & C_{23} & C_{24} \\
C_{31} & C_{32} & C_{33} & C_{34} \\
C_{41} & C_{42} & C_{43} & C_{44}
\end{array}\right]\left[\begin{array}{c}
0 \\
F_{\mathrm{mxN}}^{\mathrm{d}} \\
0 \\
F_{\mathrm{m} \times \mathrm{N}}^{\mathrm{d}}
\end{array}\right]
\end{aligned}
$$

式 (25) を変形することにより，未知数は式 (26)で求めら れ電磁界が計算できる。

$$
\left[\begin{array}{l}
F_{\operatorname{mxx}}^{\mathrm{s}} \\
F_{\mathrm{mz} 0}^{\mathrm{s}} \\
F_{\mathrm{mxN}}^{\mathrm{d}} \\
F_{\mathrm{mzN}}^{\mathrm{d}}
\end{array}\right]=\left[\begin{array}{cccc}
-1 & 0 & C_{12} & C_{14} \\
0 & 0 & C_{22} & C_{24} \\
0 & -1 & C_{32} & C_{34} \\
0 & 0 & C_{42} & C_{44}
\end{array}\right]^{-1}\left[\begin{array}{c}
0 \\
e^{-v_{0} h_{0}} \\
0 \\
0
\end{array}\right]
$$

〈3・3〉電気ダイポール＼cjkstart垂直電気ダイポール波源の人 ルツベクトルクは, 垂直磁気ダイポール波源の場合と比較 して定数俰数が異なるだけで， Sommerfeld 積分表示によ って式(27)のように表現できる。

$$
\Pi=\frac{I \ell}{\mathrm{j} 4 \pi \omega \varepsilon} \frac{e^{-j k R}}{R} \mathrm{i}_{z}
$$

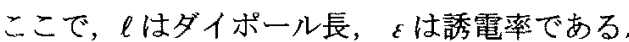

これを前述の磁気ダイポール波源の場合と同様に境界条 件を求め，逐次計算を進めていくことにより，多層媒質玉 デルに適用でき，各層における川を求めることができる ${ }^{(9)}$. また，水平電気ダイポールの場合も水平磁気ダイポールの 場合之同様にして

(29)より求められる.

$$
\begin{aligned}
& \mathbf{E}=\nabla \nabla \cdot \Pi+k^{2} \Pi \\
& \mathbf{H}=\mathrm{j} \omega \varepsilon \nabla \times \Pi
\end{aligned}
$$

〈3-4〉シールド効果の計算 シールド勃果SEの実測 は, 磁界シールドの場合, 磁気ダイポール波源より得られ た Hより式(30)で求め, 電界シールドの場合は電気ダイ

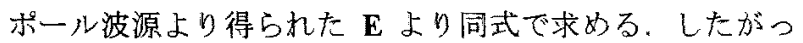
て，計算の場合も実測と同様に波源別に式 (30)よりSEを求 
める.

$S E=20 \log _{10} \frac{\left|\mathbf{H}_{0}\right|}{\left|\mathbf{H}_{S}\right|}$ or $20 \log _{10} \frac{\left|\mathbf{E}_{0}\right|}{\left|\mathbf{E}_{\mathrm{s}}\right|}$

ここで，下付き添字0は1層からN-1層の媒質にシ

ールド材を想定しない場合の観测点での電磁界,

Sはシールド材を想定したときの電磁界である.

〈3.5〉電力流の計算求めた E， H から式(31)を用い て, 電力流の時間平均値 $\mathbf{P}$ 求める.

$$
\mathbf{P}=\frac{1}{2} \operatorname{Re}\left(\mathbf{E} \times \mathbf{H}^{*}\right)
$$

ここで，Hは $\mathbf{H}$ の共役複素数である.

\section{4. 数値計算}

〈4・1〉数値計算手法 半無限積分である Sommerfeld

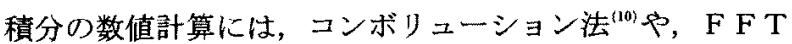
法(1)が報告されているが，ここでは，計算アルゴリズムが 容易である台形則により数值積分を行った．被積分項は数 値加算を進めていくと一定值に収束していくため，加算し ていく割合が $10^{-9}$ 以下となった時点で計算を終了した。 ま た，式(1)，(2)，(28)，(29)による電磁界は中心差分法に よる数值微分により求めた.

〈4-2〉変数变换 波源が存在する0層における直接波 成分の $\Pi_{\mathrm{m}}$ は，付録式( $\left.\mathrm{A} \cdot 1\right)$ で表され， $\lambda$ 図 $2(\mathrm{a})$ の積分 路Wで数值計算を進めていくと， $\lambda=k_{0}$ において被積分項が 発散し特異点が存在する，そこで，以下の変数変換

$$
v_{0}=\alpha+\mathrm{j} \beta
$$

を行うことにより，図2 (b) に示すような積分路となり特 異点を取り除くことができる( ${ }^{(x)}$.これを具体的に式で表す と以下となる.

$$
\begin{aligned}
\Pi_{\mathrm{an}} & =\int_{\mathrm{w}} \frac{1}{v_{0}} J_{0}(\lambda r) \mathrm{e}^{-v_{0}\left|z-h_{0}\right| \lambda d \lambda} \\
& =\int_{\mathrm{ABC}} J_{0}\left(\sqrt{v_{0}{ }^{2}+k_{0}{ }^{2}} r\right) \mathrm{e}^{-v_{0}\left|x-h_{0}\right|} d v_{0}
\end{aligned}
$$

次に図 $2(\mathrm{~b})$ に扔いて積分定数 $y$ を用いて,

$$
\begin{cases}\mathrm{A} \rightarrow \mathrm{B}: v_{0}=j(1-\gamma) k_{0} & (0 \leq \gamma \leq 1) \\ \mathrm{B} \rightarrow \mathrm{C}: v_{0}=k_{0} \gamma & (0 \leq \gamma \leq \infty)\end{cases}
$$

と変数変換を行うと， $\Pi_{\mathrm{m}}$ は以下のように変形でき，

$$
\begin{aligned}
\Pi_{\mathrm{m}} & =-\mathrm{j} k_{0} \int_{0}^{1} J_{0}\left(k_{0} \sqrt{2 \gamma-\gamma^{2}} r\right) e^{-\mathrm{j}(1-\gamma) k_{0} k-h_{\mathrm{l}} \mid} d \gamma \\
& +k_{0} \int_{0}^{\infty} J_{0}\left(k_{0} \sqrt{1+\gamma^{2}} r\right) e^{-k_{0} \gamma \gamma-h_{0}} d \gamma
\end{aligned}
$$

積分路は $\nu_{0}$ 平面上の虚軸，実軸となり特異点を解消する ことができる.

\section{5. 解析結果}

解析は図 3 に示すような内部に空隙 $d s$ を伴う 2 重シール ド材を想定して行い，実験結果との比較を行うため単層板 $(d s=0 \mathrm{~mm})$ についても解析した。

解析にあたり，波源と観測点との距離 $d=25 \mathrm{~mm}$ ，波源の位 置 $h_{0}=10 \mathrm{~mm}$, 板厚 $t=0.1 \mathrm{~mm}$ 材料とした. また, 材料は電子

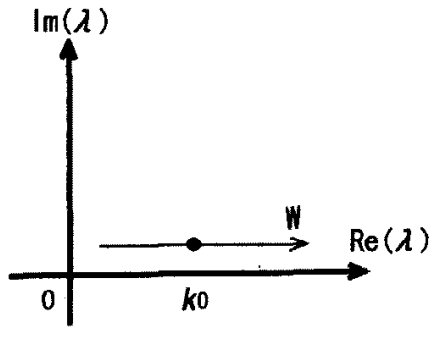

(a) Integration path on $\lambda$-plane

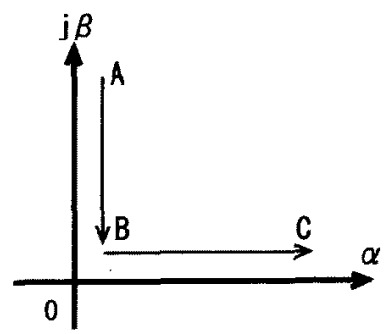

(b) Integration path on $\nu_{0}$-plane

図 2 座標变換

Fig.2 Transformation of coordinates.

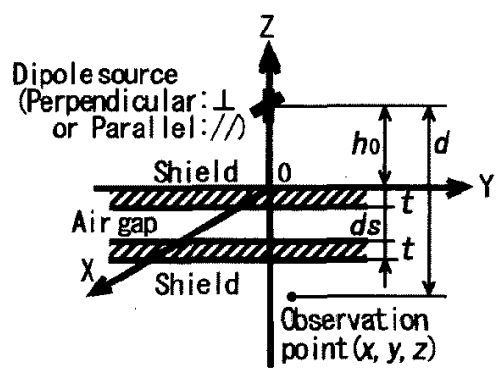

図 3 解析モデル

Fig.3 Analysis model.

表 1 材料定数

Table 1 Material parameters.

\begin{tabular}{c|c|c|r}
\hline & $\varepsilon_{\mathrm{r}}$ & $\mu_{\mathrm{r}}$ & $\sigma(\mathrm{S} / \mathrm{m})$ \\
\hline $\mathrm{Cu}$ & 1 & 1 & $5.81 \times 10^{7}$ \\
\hline $\mathrm{Al}$ & 1 & 1 & $3.64 \times 10^{7}$ \\
\hline
\end{tabular}

機器によく用いられている銈CuアアルミニウムAlを想定し， 表 1 の材料定数（比誘電率 $\varepsilon \mathrm{r}$, 比透磁率 $\mu$, 導電率 $\sigma$ ) を 用いた.

〈5・1〉実験結果との比較 実験は悈アドバンテスト社 製のシールド効果評価器(型式:TR17301)を用いた。試料寸 法は $200 \mathrm{~mm} \times 200 \mathrm{~mm}$ である. 測定器のダイナミックレンジの 都合上，磁気ダイポール波源に関して $10 \mathrm{kHz} \sim 300 \mathrm{kHz}$ の周 波数带で測定を行った。

シールド材に対して磁気ダイポール軸が垂直 (上)の場 合，水平 $(/ /)$ の場合，あるいは材料間に空隙を設置した場 合の解析結果と実験結果とのSEの比較を図 4 に示す．実線 


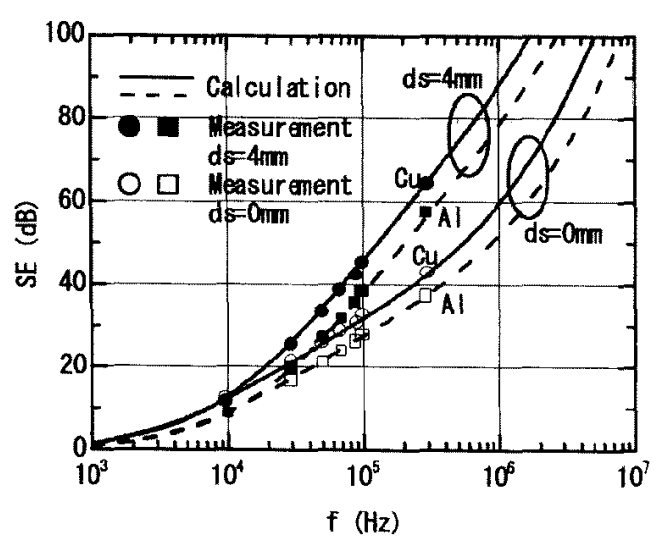

(a) Dipole $\perp$ Shield

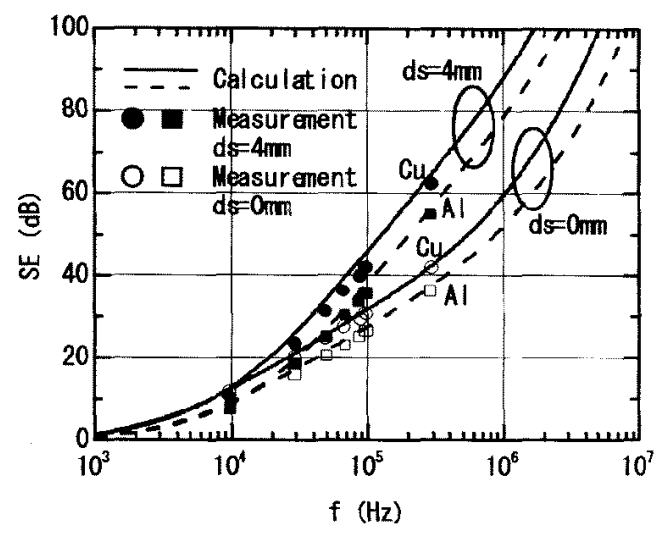

(b) Dipole // Shield

図 4 磁気シールド効果の計算結果と実験結果

Fig.4 Calculation and experimental results of magnetic shielding effectiveness.

と破線はそれぞれCu，A1材に対する計算結果を示す。これ より，解析結果は実酫結果とよく一致しており，本解析手 法が適切であることが㭲証できた。

また，垂直磁気ダイポール波源と水平磁気ダイポール波 源とのシールド効果はほぼ一致しており，SEさ波源の向き によって変わらないことが確認できた。

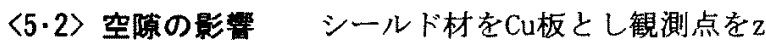
軸上におき，空隙dsを変更した場合のSEへの影響を解析し た. 図 5の結果より，空隙を大きくしていくことによりSE が向上し，周波数が高いほど空㩐の影響がでやすいという 傾向を示した，また，磁気ダイポールの場合は垂直設置， 水平設置の違いでSEに変化はほとんど見られないが，電気 ダイポール波源の場合は空吵の設定により垂直設置の場合 にSEが急激に高くなることが確想できた。この理由につい ては，電力流の概念を用いて次節で考察する.

〈5.3〉シールド材近搒における電力流 シールドのメ カニズムを明らかにするために，ダイポール波源から放射 された電力流の時間平均值(平均ボインティングベクトル) が，シールド材の設置により，どのように変化するかを求 めた.ここでは，特に空隙の影響が顕著であった垂直ダイ

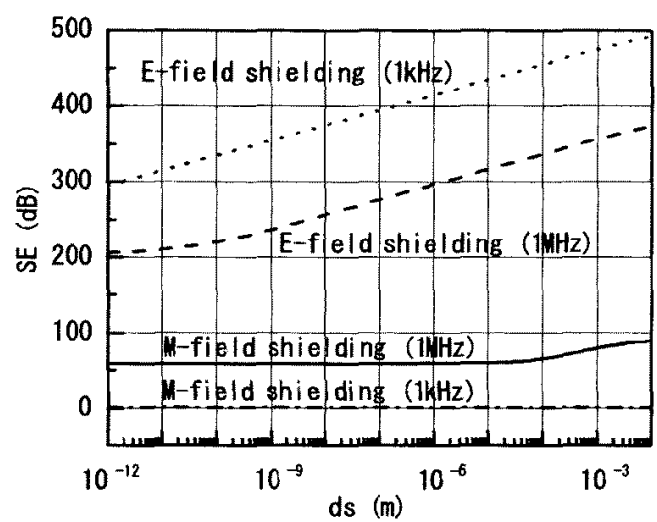

(a) Dipole $\perp$ Shield

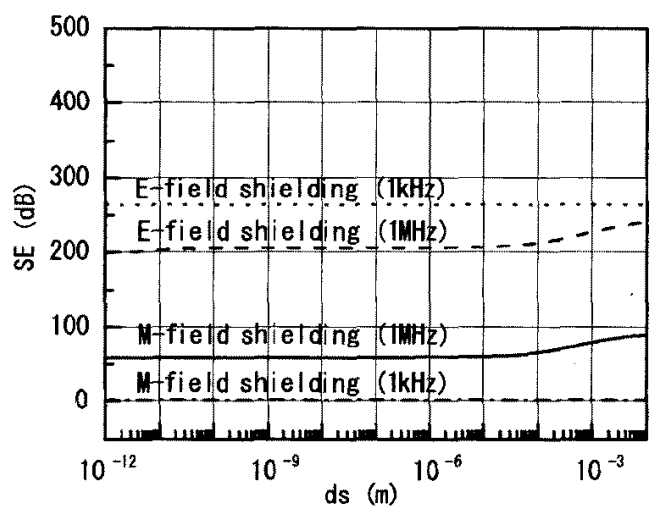

(b) Dipole // Shield

図 5 空隙の変更によるシールド効果への影響

Fig.5 Air gap effects on shielding effectiveness.

ポール波源の場合について解析を行った．解析にあたりシ ールド材としてCu板 $(t=0.1 \mathrm{~mm})$ を仮定し，各種パラメータ を $=1 \mathrm{MHz}, I=1 \mathrm{~A}, \pi=1, S=100 \mathrm{~mm}^{2}$ (磁気ダイボール), 及び $\ell$ $=10 \mathrm{~mm}$ (電気ダイポール)として計算を行った.

図 6，7に磁気ダイポール波源から放射された電力流を 示す.シールド材がない場合はダイポール波源から放射さ れた電力流は放射状に広がることは知られているが、シー ルド材がある場合は、シールド材に電磁波が引き寄せられ， そしてx力向に流れ電力を消費することによって，電磁波 が遮蔽されている様子が見られた．次にシールド材に $d s=4$ mnの空隙を設けた場合は空隙内で電力流がわずかではある がx方向に向きを変えている。したがって，磁気ダイポー ルと同一軸 $(\mathrm{z}$ 軸) 上にある観測点でシールド効果を評価す る場合は，その点での電力流が弱められるため，SEが向上 することが推察できた。

次に，図 8，9に電気ダイボール波源の場合の電力流を 示す。これらの図より磁気ダイポール波源の場合と比較し て，シールド材近傍において㐅力向一多くの電力が流れて いることがわかった。すなわち，シールド材に電磁波が流 九込む磁畧シールドより，透過波が少なくなりSEが高くな ることが類推できた。また，図 9 より空隙部分ではほとん 


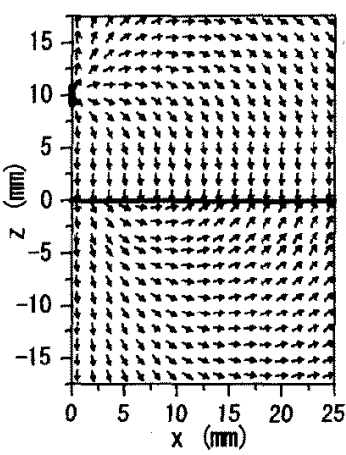

(a) Direction

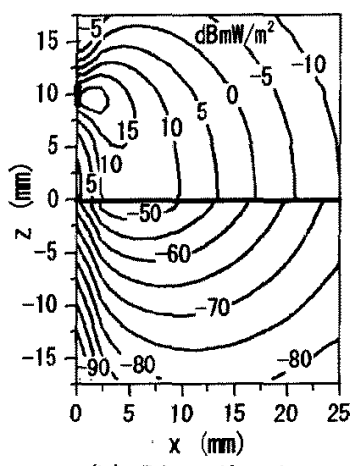

(b) Distribution
図 6 磁気ダイポール波源からの電力流 $(d s=0 \mathrm{~mm})$

Fig.6 Poynting flux radiated from a magnetic dipole source. $(d s=0 \mathrm{~mm})$

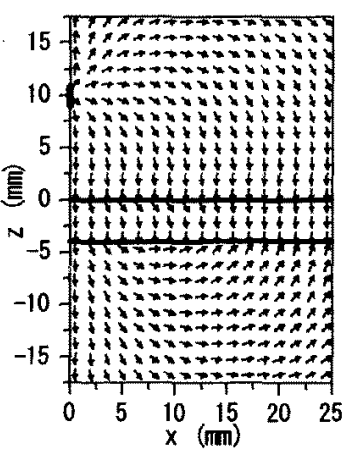

(a) Direction

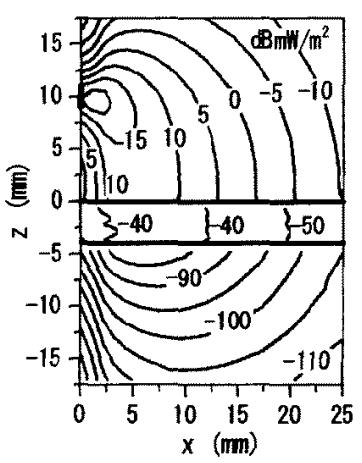

(b) Distribution
図 7 磁気ダイポール波源からの電力流 $(d s=4 \mathrm{rm})$

Fig.7 Poynting flux radiated from a magnetic dipole source. $(d s=4 \mathrm{~mm})$

どの電磁波成分はx方向へ流れるため, 単層板よりシール ド性能が向上することが確認できた．同図(b)より，単層 シールドの場合と比較してシールド材下部において，波源 からの電力が極端に小さくなることが見られた，したがっ て，垂直電気ダイポール波源では，空隙がSEに非常に大き く関与することがわかった.

周波数を変更した場合も磁気，電気ダイボールともに波 源から放射された電磁波は，前述と同様な形態でシールド 材に流れ込み，これに沿って電力流が移動する様子が確铇 できた，しかし，周波数の違いによってシールド板で消費 される電力流の大きさも異なるため，図4のようにSEは周 波数依存性示した。

\section{6. むすび}

球面波を円筒波の積分表示式で表現する Sommerfeld 積 分を用いて，磁気，あるいは電気ダイポール波源を伴う多 層媒質近傍の電磁界を理論解析的に式を導出し，部算によ って求めることを詎みた，検証のため，金属板を想定し，

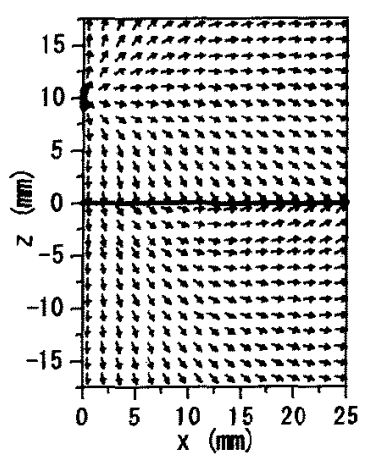

(a) Direction

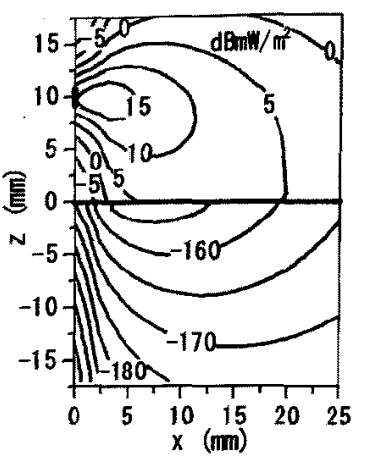

(b) Distribution
図 8 電気ダイポール波源からの電力流 $(d s=0 \mathrm{~nm})$

Fig.8 Poynting flux radiated from an electric dipole source. $(d s=0 \mathrm{~mm})$

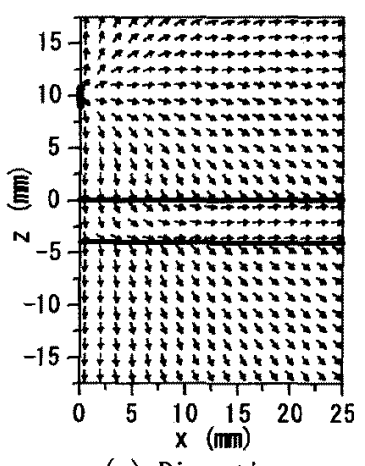

(a) Direction

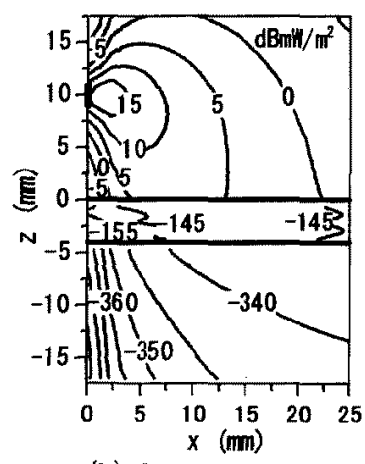

(b) Distribution
図 9 電気ダイポール波源からの電力流 $(d s=4 \mathrm{~mm})$

Fig.9 Poynting flux radiated from an electric dipole source, $(d s=4 \mathrm{~mm})$

単層,及び多層媒質の近傍界シールド効果を解析した結果, 実験結果とよく一致しており本解析手法の妥当性を確認し た，次にシールド材を多層構造とした場合の空隙の影響 を調べたところ，材料閒の空隙を大きくすることによりシ 一ルド効果が向上することを確かめた，また，シールド材 近傍，あるいは内部における電力流の時間平均值を求める ことによりシールドのメカニズムを検討した，その結果， ダイポール波源から放射された電磁波はシールド材に流れ 込み，これに沿って平均電力流が移動することによりシー ルド効果が得られることを示した.

本計算手法はシールド効果や媒質内部の電磁界を䚺算で きるほか，地中，あるいは海中等の電気定数が層状に分布 している場の解析も可能である。すなわち，理設物，鉣脈， あるいは油田等の電磁波による挆査解析に応用ができるも のと考えられる。

今後に残された課題としては，異方性媒質を取り扱う問 題や，多点波源を有するシールド材の近傍や内部電磁界を 明らかにすることである。 
甜 辞

本研究は，科学技術庁の平成 11 年度科学技術振興調整 費による地域先導研究「地域産業の発展に奇与する電磁波 技術に関する研究（シールド効果测定法の開発と評価）! の一睘として行われた。

(平成12年6月 29 日受付, 平成12年10月 12 日再受付)

\section{文 献}

（1）清水康敬・柊浦行：”電磁妨害波の基本と対策”，(社) 電子情報通信学会，56～77（1995-9）

（2）長尾泰司，西方敦博，清水康敬：”シェル夕ノフの電 磁シールド効果式の誤差と補正”，信学諭（B-II）， J77-B-II, No. 12, 804 812 (1994-12)

(3) A. Nishikata and A. Sugiura: "Analysis for Electromagnetic Leakage through a Plane Shield with an Arbitrarily-0riented Dipole Source", IEEE Trans. Electromagn. Compat. , vo1. 34, No1, 284 291 (1992-12)

（4）山口尚，雨宮好文，林孝広：”多層媒質による平面波 の電磁シールド効果”，信学技報，EMCJ93-77，7〜14 (1994-1)

(5) R. Yang and R.Mittra : "Coupling Between Two Arbitrarily Oriented Dipoles Through Multilayered Shields", IEEE Trans. Electromagn. Compat., vol. EMC-27, №3, 131 136 (1985-8)

(6) 長野勇 : “不均質媒質中の電磁波伝搬”，明友印刷㑣， $12 \sim 42(1997-1)$

(7) J.A.Stratton:" Electromagnetic Theory", McGraw -Hi11, New York, 573 577 (1941-1)

（8）安斎弘樹，山渏隆，内藤善之，水本哲弥：”ジムフェ ライト装荷フェライト系電波吸収体を用いた電波半無 響室のソンマーフェルト積分式による解析の検討”， 信学技報，EMCJ94-60，71～78 (1994-11)

（9）吉村慶之，長野勇，横本広章，大浦利夫，八木谷聡： ”電気ダイポールの任意位㯰にお打る多層媒質のシー ルド効果”，信学技報，EMCJ99-127，105 112（2000-1）

(10) A. Orr, D. L. Jones, S. Lovell, and G. Garnett : "Calculation of Fields from a Horizontal Electric Dipole Source in Sea Water Using Linear Digital Convolution", 2nd report of work undertaken under DERA Research Agreement SSDW3/0002, $1 \sim 53(1998-3)$

(11) A. Orr, D. L. Jones, and G. Garnett: "Numerical Evaluaton of Electromagnetic Fields from a Submerged Dipole Source Using the Fast Fourier Transform", 3rd report of work undertaken under DERA Research Agreement SSDW3/0002, 1 35 (1999-3)

\section{付 録}

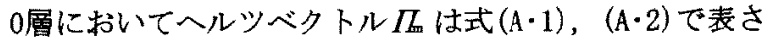
れる。また1層にお゙いては，式(A・4)，(A·5) となり，合成 した式(A·3)，(A-6)を境界条件式(3)，（4）に代入すること により式 $(A \cdot 7)$ に示す関保が求まる.

$$
\begin{aligned}
& \Pi_{\mathrm{m} z 0}^{\mathrm{p}}=\frac{n S I}{4 \pi} \int_{0}^{\infty} \frac{1}{v_{0}} J_{0}(\lambda r) e^{-\nu_{0}\left|z-k_{0}\right|} \lambda d \lambda \\
& \Pi_{\mathrm{m} z 0}^{\mathrm{s}}=\frac{n S I}{4 \pi} \int_{0}^{\infty} F_{m z 0}^{s}(\lambda) J_{0}(\lambda r) e^{-v_{0} z} \lambda d \lambda \\
& \Pi_{\mathrm{mz} 0}=\Pi_{\mathrm{mz} 0}^{\mathrm{p}}+\Pi_{\mathrm{mz} 0}^{\mathrm{s}} \\
& \Pi_{\mathrm{mz} 1}^{\mathrm{u}}=\frac{n S I}{4 \pi} \int_{0}^{\infty} F_{\mathrm{mzz}}^{\mathrm{u}}(\lambda) J_{0}(\lambda r) e^{-v_{1} z} \lambda d \lambda \\
& \Pi_{\mathrm{mz} 1}^{\mathrm{d}}=\frac{n S I}{4 \pi} \int_{0}^{\infty} F_{\mathrm{mzz}}^{\mathrm{d}}(\lambda) J_{0}(\lambda r) e^{\nu_{\mathrm{I} z}} \lambda d \lambda \\
& \Pi_{\mathrm{m} z 1}=\Pi_{\mathrm{m} \geq 1}^{\mathrm{u}}+\Pi_{\mathrm{m} \geq 1}^{\mathrm{d}} \\
& {\left[\begin{array}{c}
F_{\mathrm{m} 20}^{\mathrm{S}} \\
e^{-v_{0} h_{0}}
\end{array}\right]=\frac{1}{2 \mu_{0} v_{0}}\left[\begin{array}{l}
\mu_{1} v_{0}+\mu_{0} v_{1} \\
\left(\mu_{1} v_{0}-\mu_{0} \nu_{1}\right) \nu_{0}
\end{array}\right.} \\
& \left.\begin{array}{l}
\mu_{1} v_{0}-\mu_{0} v_{1} \\
\left(\mu_{1} v_{0}+\mu_{0} \nu_{1}\right) \nu_{0}
\end{array}\right]\left[\begin{array}{l}
F_{\mathrm{mzl}}^{\mathrm{u}} \\
F_{\mathrm{mzl}}^{\mathrm{d}}
\end{array}\right] \\
& =\left[\begin{array}{ll}
c_{011} & c_{012} \\
c_{021} & c_{022}
\end{array}\right]\left[\begin{array}{l}
F_{\mathrm{mz2}}^{\mathrm{u}} \\
F_{\mathrm{m} 21}^{\mathrm{d}}
\end{array}\right]
\end{aligned}
$$

ここで，上付き添字Pは直接波，S梳反射波を表す。

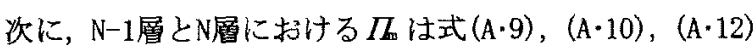
で表される，これらを合成した式(A・11)，(A-13）を境界条 件式 (3)，（4)に代入することにより，未知数 $F_{\mathrm{ax}}$ は $(A \cdot 14)$ の関係が得られる.

$$
\begin{aligned}
& \Pi_{\mathrm{m} z \mathrm{~N}-1}^{\mathrm{u}}=\frac{n S I}{4 \pi} \int_{0}^{\infty} F_{\mathrm{m} z \mathcal{N}-1}^{\mathrm{u}}(\lambda) J_{0}(\lambda r) e^{-v_{N-1}\left(z-z_{N-2}\right)} \lambda d \lambda \\
& \Pi_{\mathrm{mzN}-1}^{\mathrm{d}}=\frac{n S I}{4 \pi} \int_{0}^{\infty} F_{\mathrm{mzN}-1}^{\mathrm{d}}(\lambda) J_{0}(\lambda r) e^{\mathrm{v}_{N-1}\left(z-z_{N-2}\right)} \lambda d \lambda \\
& \Pi_{\mathrm{mz} N-\mathrm{I}}=\Pi_{\mathrm{mzN}-1}^{\mathrm{u}}+\Pi_{\mathrm{mzN}-1}^{\mathrm{d}} \\
& \Pi_{\mathrm{m} 2 \mathrm{~N}}^{\mathrm{d}}=\frac{n S I}{4 \pi} \int_{0}^{\infty} F_{\mathrm{m} z \mathrm{~N}}^{\mathrm{d}}(\lambda) J_{0}(\lambda r) e^{\nu_{S}\left(z-z_{N-1}\right)} \lambda d \lambda \\
& \Pi_{\mathrm{mzN}}=\Pi_{\mathrm{mzN}}^{\mathrm{d}} \\
& {\left[\begin{array}{l}
F_{\mathrm{mzN}-1}^{\mathrm{u}} \\
F_{\mathrm{mzN}-1}^{\mathrm{d}}
\end{array}\right]=\frac{1}{2 \mu_{N-1} v_{N-1}}\left[\begin{array}{l}
0 \\
0
\end{array}\right.} \\
& \left.\begin{array}{l}
\left(\mu_{N} v_{N-1}-\mu_{N-1} v_{N}\right) e^{v_{X-1} h^{h} h_{N-1}} \\
\left(\mu_{N} v_{N-1}+\mu_{N-1} v_{N}\right) e^{-v_{N-1} h_{N-1}}
\end{array}\right]\left[\begin{array}{c}
0 \\
F_{\mathrm{mz} N}^{\mathrm{d}}
\end{array}\right] \\
& =\left[\begin{array}{ll}
c_{\mathrm{N}-111} & c_{\mathrm{N}-112} \\
c_{\mathrm{N}-121} & c_{\mathrm{N}-122}
\end{array}\right]\left[\begin{array}{c}
0 \\
F_{\mathrm{m} 2 \mathrm{~N}}^{\mathrm{d}}
\end{array}\right]
\end{aligned}
$$

式(A・8)，式(A・15)，及び本文式(10)は濑化式であるた め，まとめると本文式(11) が得られる. 


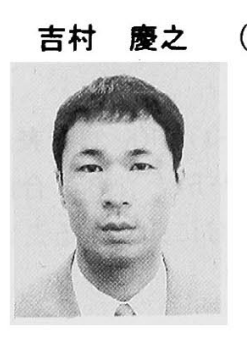

（学生員）1990年長岡技術科学大学大学院 修士課程了. 同年石川県工業試験場勤 務. 2000 年金沢大学大学院博士後期課 程社会人留学. 現在, 環境電磁工学, 特に電磁波の遮蔽と吸収に関する研究 に従事. 電子情報通信学会会員

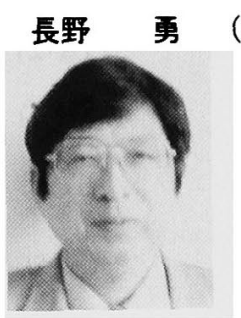

（正員）1970年金沢大学大学大学院修士課 程了. 同年同大工学部電気工学科助手. 1983年〜1984年米国ジェット推進研究 所NRC研究員. 1987年同大工学部電気 ・情報工学科教授. 2000 年同大総合情 報処理センター長, 情報システム工学 科教授. 異方性不均質媒質中の電磁界 計算法, VLF波によるD層電子密度計算法の開発, 衛星搭載 用プラズマ波動観测装置 (EXOS-D, GEOTAIL，のぞみ)の開 発に従事. 工博. 1987年地球電磁気・地球惑星圈学会田中 館賞受賞. 1998年NASA Group Achievement Award受賞. 電 子情報通信学会, 地球電磁気 - 地球惑星圈学会, 米国地球 物理学会各会員.

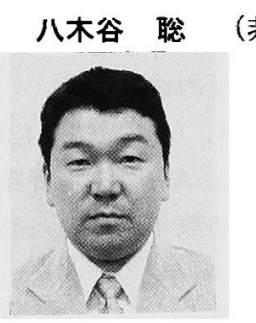

非会員）1990年金沢大学大学院修士課程 了. 1993年同大大学院博士課程了. 同 年同大工学部電気・情報工学科助手. 現在同大工学部情報システム工学科助 教授、科学衛星およびニンピュータシ ミュレーションによる磁気圈プラズマ 波動解析の研究, 火星探査衛星（のぞ み）搭載用低周波波動観測装圈の開発に従事. 工博. 電子 情報通信学会, 地球電磁気・地球惑星圈学会, 米国地球物 理学会各会員.

大浦 利夫 (非会員) 1960年石川県工業試験場勤務.

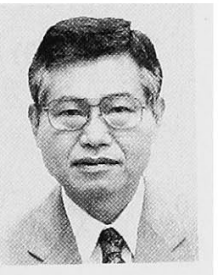
同所情報指導部主任研究員を経て，現 在，機械電子部部長.（社）日本溶接 協会石川県支部副支部長, 石川県電気 使用合理化委員会委員. 精密測定, 精 密加工に関する研究に従事. 